\title{
Western Samoa Trade Unionism: the 1981 Public Service Strike
}

\section{Rick Snell *}

I have used a proposition developed in Kerry Howe's seminal work Where the Waves Fall (1984) to offer an explanatory framework for understanding industrial relations in the South Pacific. The paper concentrates on applying this analysis to a key moment in Western Samoan industrial relations, the 1981 public service strike. The key concept used in this analysis is mutual adjustment. The concept refers to an interactive process between foreign institutions, such as trade unions, and pre-existing institutions and values like fa' a Samoa (the cultural and political value system of Western Samoa). While the 1981 strike, and South Pacific industrial relations in general, can be interpreted from a number of perspectives the approach used in this paper may offer a method that does not obscure the full interplay between Western values and institutions and local forces.

\section{Introduction}

This article examines the background and events surrounding the 1981 public service strike in Western Samoa. At the time the strike was described as the most important event in modern Samoan history second only to the Mau rebellion against the New Zealand administration (Pacific Islands Monthly, July 1981, p.13). ${ }^{1}$ From 6 April to 2 July 1981 , a period of 90 days, Western Samoans experienced for the first time a prolonged period of organised industrial unrest which affected the vast majority of Western Samoa's small but vital wages and salary sector. The 1981 strike brought into sharp focus a number of issues including the dynamic interaction between tradition and modernity in the process of institutional transfer, the role trade unionism can play as a vehicle for elite mobilisation, especially on a generational basis, and the trend from localisation to politicisation of the Samoan labour movement. These factors have continued to play fundamental parts in Western Samoan politics in the decade since 1981. The industrial turmoil of 1981 represents a watershed in Western Samoan labour history and is therefore a convenient terminus for this particular study.

I have analysed the strike, and consequently the role of the Public Service Association and the Western Samoan government, as an aspect of the process of mutual adjustment in terms of institutional transfer. From this perspective the 1981 strike was a sharp confrontation between adopted European institutions and value systems (of both the strikers and the government) with Samoan values and methods of dispute settlement. The first part of this article explains the form of analysis I have used. Secondly, the article concentrates on trade unionism in Western Samoa until the end of the strike in 1981.

Lecturer in Law, University of Tasmania, Australia

'See Field, 1984 for a detailed coverage of this period of Samoan history. 


\section{Institutional transfer}

Studies of trade unionism in the South Pacific are in their infancy comparatively. This interest is growing for the South Pacific region while trade union studies in other regions are on the decline (Hess, 1986; Leckie, 1990). There has been a surprising shortfall in academic writing on trade unions in developing countries (Sclafani, 1977). The surprise is caused by the discrepancy between the amount of available material and the acknowledged importance of trade unions. This importance was particularly stressed in the political science literature devoted to modernisation studies (e.g., Kassalow, 1969, pp.303, 308-320; Friedland, 1972). Despite prominence being given to trade unions and their roles in various literature, especially modernisation studies or works on dependency theory, there exists only a relatively small number of individual studies of trade unions or single country case studies (see Friedland,1972; Epstein, 1978; Tyler, 1982; Kassalow, 1969; Ananaba, 1979).

A proposition borrowed from Pacific historiography provides an interesting analytical framework to study the development of trade unionism within the South Pacific region. This proposition was advanced by Kerry Howe in Where the Waves Fall (1984). He considered that studies of the South Pacific have tended to downplay the degree and dynamic nature of the interplay between local culture and institutions with external forces. The argument is that a process of mutual adjustment occurs with changes taking place within the local system and upon the introduced institution.

I have examined the merits of this argument using the Public Service Association of Western Samoa (WSPSA) as an example of institutional transfer to Western Samoa accompanied by a process of mutual adjustment. The 1981 strike serves as an extremely useful centre piece because it represented such a clear clash between the forces of modernity and tradition. The strike also demonstrated that mutual adjustment is not necessarily a peaceful process. Felise Va'a has described the conflict between the WSPSA and the Public Service Commission (PSC) in the following manner:

In Western Samoa's recent past, only the Mau Movement may have provoked divisive, emotional responses comparable to those engendered by the strike. Families often were split apart over the issue, with members supporting either the PSA or the PSC. Coming in the final year of Tupuola's three-year term, the strike became its dominant event and it was responsible directly for the decline and fall of his political empire as it existed up to that time. With virtually every public servant on strike, able to recall with some bitterness the hunger, deprivation and financial insecurity caused by it, Tupuloa's government had many determined opponents as the 1982 elections approached.

Even in industrialised Western societies, strikes by public servants - a fairly recent phenomenon - arouse considerable public disquiet. The situation was even more pronounced in Western Samoa, which has no tradition of trade union activity or strike action, a social structure based upon close-knit family ties and consensual decision-making processes, and a very large public service in proportion to the total workforce (Va'a , 1983, p.91).

\section{Mutual adjustment}

Mutual adjustment, as a descriptive term, covers an interactive process between introduced elements and pre-existing institutions and values. The term mutual does not presuppose that this interaction occurs on the basis of equality between the introduced and the pre-existing elements. The relationship is not symmetrical. Often the initial stage of this interaction sees a domination by the introduced values or institutions over their pre-existing 
counterparts. Despite an apparent initial domination the more fundamental pre-existing elements force an adjustment in the introduced institution to accommodate them. With time, more of the pre-existing elements tend to re-emerge onto the public arena. Nevertheless such a process usually produces important qualitative and quantitative changes to the arrangements in place prior to the introduction of these external values and institutions.

\section{Mutual adjustment and its application to Western Samoa}

Howe (1984) has made a very strong case for the suitability of using the idea of mutual adjustment or a process of accommodation to pre-colonial studies of the South Pacific. The concept of mutual adjustment appears to provide a more sensitive framework within which to analyse the interaction between European influences and the indigenous political system. I would argue that the mutual adjustment model is a much more sensitive analytical approach and has a better explanatory value than approaches based around the often used traditional versus modern polarity (see Riggs 1967, 317-349; Rustow, 1968; Huntington and Dominguez, 1975, pp.1-114; Larson, 1980; Hoogvelt, 1977, chapter 3; Rivkin, 1969). Mutual adjustment centres attention on the process and impact of change. This approach also avoids the neglect of pre-existing institutions and values in academic fields outside anthropology.

Recourse to a mutual adjustment approach avoids settling for an institution transfer formula that posits " $x$ was totally replaced with $y$ ". Rather it considers whether $x$ persists and if so the nature and form of $x$. This approach also considers what, if any change, has occurred to the nature and function of $y$ as a result of the dynamics of its interaction with the culture or system that produced $x$. Kerry Howe advanced the proposition that the process of interaction between Islanders and Europeans was heavily influenced by the initiatives of Islanders and by their social and political arrangements rather than by European decree. This proposition is by no means unique to Howe (see Davidson, 1967). Howe has restricted his arguments to the period of precolonial culture contact in the South Pacific. However he argues that the relevance of his thesis is becoming more apparent in relation to the postcolonial experiences of South Pacific countries.

The remainder of this article deals with a brief history of trade unionism in Western Samoa, especially the Public Service Association, up to the end of the 1981 strike. The strike, and consequently the role of the WSPSA, is analysed from the perspective of a process of mutual adjustment. What occurred was a sharp confrontation between adopted institutions and value systems (by both strikers in the form of a trade union and the government in the form of legislation based on Western premises of industrial relations) with Samoan values and methods of dispute settlement.

\section{Trade unionism in Western Samoa}

Unionism in Western Samoa, until the 1970s, appears to have been low-keyed, for some years largely the reserve of New Zealanders working in the public service and in later years as an arena for factional struggles between public sector workers. This apparent state of affairs may only be due to a lack of field studies. The other interesting and associated feature is the high level of dual membership especially at the executive level between the public sector unions, especially between the WSPSA and the Western Samoan Teachers' 
Association (de Bres, 1980, p.1). The WSPSA claims to have been the only union in Western Samoa in the early 1950 s but the Western Samoan Teachers' Association also dates its beginnings from the 1950 s.

Private sector unions or labour organisations have been rare in Western Samoa. There has been a small group of pilots called the Western Samoan Airline Pilots' Association and an association of taxi drivers, whose principal role was to lobby for higher fares for owner drivers (de Bres, 1980, p.3). Given the public sector dominance of the small salary and wages sector of the Western Samoan economy this absence of private sector unions prior to the 1980 s is not surprising. ${ }^{2}$

\section{Industrial action in Western Samoa prior to 1981}

A general pattern of spontaneous walkouts rather than organised, premeditated industrial action marked the history of industrial relations in Western Samoa until 1980 (de Bres, 1980 pp.2-3). The 1981 strike presented the Western Samoan government with a new type of problem, organised industrial action within the strategically vital but numerically small wages and salary sector. More importantly this occurred within the previously tranquil arena of government employment. It also featured a conflict between $\mathrm{fa}^{\prime} \mathrm{a}$ Samoa and an institution modelled on Western values, a trade union, the newly reformed and reconstituted WSPSA. ${ }^{3}$ Prime Minister Tupuola, after the 1981 strike, said "It's true there were strikes before - but never at such strength." (Pacific Islands Monthly, July 1981, p.13).

\section{The Public Service Association of Western Samoa}

The WSPSA has been the largest and most active public service employee organisation in pre and post independence Western Samoa. The following material on the early period of Western Samoan trade unionism and the WSPSA, in particular, relies heavily on Joris de Bres's 1980 report. The organisation had a chequered history with several metamorphoses. It began life as an association of New Zealanders working in the colonial administration prior to 1962 . During the latter years of the 1960 s and the majority of the 1970 s the WSPSA appears to have been a typical white collar compliant union which caused governments little angst and struggled to maintain membership or generate interest among members. In mid 1978 the WSPSA was formally deregistered for failing to lodge annual returns and accounts. During the years 1979-1981 the WSPSA was resurrected largely due to a contingent of younger activists and a degree of assistance from the New Zealand Public Service Association. Prior to the 1981 strike the membership of the WSPSA had reached 3,000 but this was still only about 40 percent of its total potential membership.

After independence in 1962, the WSPSA largely served as an umbrella organisation whose executive positions served as items of contention by various sectional groupings of public servants. The groupings consisted of nurses, teachers, post office workers and members

\footnotetext{
${ }^{2}$ South Pacific Commission, 1981 pp.22-29. The actual number of public servants in 1981 was approximately 7,000 with a further 2,000 people employed by the Western Samoan Trust Estate Corporation. The total wages and salary sector was about 16,000 employees including police, politicians and legal officers.

${ }^{3} \mathrm{Fa}$ ' a Samoa (the Samoan Way) is the term used to describe the culture of Samoa.
} 
of the Marine Department. There is no indication, in de Bres's report, why these positions would be a source of such contention. If the union was on the wane during this period the prize of office holding would appear relatively unimportant. One possible answer could be that, although relatively powerless and ineffectual, the ceremonial and prestige values attaching to union positions would serve as a source of $f a^{\prime} a$ Samoa prestige. This formal prestige would help the incumbents in their dealings with the government involving the interests of their own sectional and family supporters.

The origins of the 1981 dispute can be traced back, at least in part, to the passing of the Samoan Public Service Act (1977). The Act was modelled closely on the New Zealand State Services Remuneration and Conditions of Employment Act 1977. However the Samoan Public Service Act (1977) had no provisions for arbitration and conciliation in the event of a dispute nor any requirement to consult employees or their representatives when changes were made to working conditions (Wood, 1980). The provisions for the public service were in contrast to the New Zealand act and the legislation covering employment in the Samoan private sector, the Labour and Employment Act 1972 (see Tuiasau, 1982, pp.75-76). The omission and the associated political attitude that led to the exclusion of these provisions was to be one of the major points of contention during the 1981 strike. Marion Wood claimed that:

\begin{abstract}
Philipp Muller, former chairman of PSC said that provisions for conciliation and arbitration contained in earlier drafts of the bill were excluded because the prevailing attitude among politicians was anti-union and without representation from employee organisations, these provisions were lost along the way without any strong protest being made (Savali, 20 February 1980).
\end{abstract}

In 1979 the WSPSA re-emerged onto the industrial relations scene in Western Samoa. It presented its papers for incorporation to the Registrar of Incorporated Societies claiming coverage of all public servants, including teachers and statutory authority staff, but not the 2,000 staff employed by the Western Samoan Trust Estate Corporation. A general meeting of over 400 public servants voted in favour of the proposed WSPSA constitution and structure. The previous problem of executive dominance by sectional interests was dealt with by the creation of a nine member Management Council on which each sectional grouping was restricted to a maximum of two representatives.

Immediately after the new WSPSA was formed union officials voiced a number of concerns about the 1977 Public Service Act. Such matters of concern not only included the absence of dispute settling procedures but also discrepancies in conditions of service in comparison to wage workers in the private sector. Similar concerns were raised by the PSC. The problems for the PSC centred on the absence of dispute settling procedures but extended to the absence of provisions allowing the PSC to cope with any industrial unrest especially in providing essential services. The government considered the legislative shortcomings unimportant as industrial action appeared to be totally alien to the operations of fa' a Samoa. Therefore a strike problem, in the eyes of the political leadership, would not eventuate. If such action was to occur the traditional dispute settling procedures of $f a^{\prime} a$ Samo $a$ would come into play and avert any serious trouble.

After 1979, with the revival of the WSPSA and the potential problems with the 1977 legislation, all the ingredients for a process of mutual adjustment to occur were in place. First, a government adopting industrial legislation based on foreign models but omitting important components with the expectation that traditional Samoan elements would automatically and harmoniously replace these exclusions. Second, a younger generational 
group with leadership aspirations, not accommodated as yet into the traditional power structure, had with considered deliberation adopted an institutional structure derived from foreign sources, a trade union. Third, this new institution operated on the presupposition that dispute settling procedures granted a rough equivalency in bargaining position between the warring parties. The concept of bargaining equivalency, on these grounds, was totally alien to the mindsets of the political leadership of Western Samoa. Prior to 1981 a strike within the public sector would have been considered by the government unimaginable or at the very least, just another conflict to be resolved in the normal Samoan way.

\section{The 1981 strike: immediate cause of the strike}

The immediate cause of the outbreak in industrial unrest was the extreme vulnerability and fragility of Western Samoa's subsistence economy. From 1962 onwards the Western Samoan economy remained seriously weak. 1979 statistics show how the economy relied almost exclusively on two principal exports, copra ( 54 percent) and cocoa ( 23 percent). The Samoan workforce was concentrated in primary production (approximately 80 percent) especially in subsistence farming. A series of trends continued during the 1970 s which threatened Samoa's already weak economy. Population levels continued to rise but were not accompanied by an increase in food production. Export production volumes had significantly decreased during the previous 20 years. The 1973 oil crisis and the subsequent world wide economic recession exerted tremendous strains upon Western Samoa's exports and imports.

\section{Government response to the economic problems}

After a series of solutions had proved ineffectual in significantly redressing the problems facing the Western Samoan economy the government turned to more drastic remedies. In June 1979, the dollar was devalued by 15 percent. Interest rates, petrol prices and electricity charges were increased. Within two days of the devaluation announcement, officials of the new WSPSA had met and discussed their reactions. The WSPSA resolved to pursue a 30 percent wage increase for its members. The union sought to preserve the standard of living for public servants who were largely dependent upon purchased goods and subject to traditional demands upon their cash incomes from their aiga (family group) and village. After negotiations, between the PSC and the WSPSA, a compromise solution was reached, but not formally approved by cabinet until later in the year. The agreement was for a 10 percent increase in June 1980 and a 12 percent second phase increase to follow in January 1981 (Tuiasau, 1982, p.78).

The government without explanation, in December 1980, decided to ignore the agreement. When the financial estimates for 1981 were tabled in parliament they contained provision only for an 8 percent second phase increase to be paid in two stages separated by a six month interval, as opposed to the WSPSA-PSC agreement of an immediate 12 percent increase from January 1981. As a compromise the Cabinet approved amendments to the Income Tax Act to provide an increase in the level of non-taxable income so as to boost the take home pay of wage workers.

The WSPSA executive's reaction to the government's decision was to treat the breach of agreement as an industrial dispute. New to such action, the union executive was faced 
with the major problem of running such a dispute. The Cabinet backdown on the WSPSA-PSC agreement had shown that pressure on the PSC would not be effective. To undertake strike action was seen as a measure of last resort. The union faced problems in undertaking such drastic action only 25 months after its re-establishment. There were three key stumbling blocks. First, the union executive did not know how their recently recruited membership would respond to such a call to industrial action. Second the very concept of strike action was alien to traditional Samoan approaches to dispute settlement. Third, the union leadership risked the possibility of being labelled traitors to Western Samoa development and posing a serious threat to their families by shutting down the key public sector upon which many Samoan families relied for access to cash.

Kinloch (1982) has provided an analytical framework using the dispute settling procedures of $f a^{\prime}$ a Samoa to interpret the 1981 strike. This framework dovetails with the concept of mutual adjustment. The model has a number of stages patterning the normal steps in Samoan dispute resolution. First, a disagreement is created. Secondly, the parties set about gathering support for their claims. During this process neither party will directly speak to each other. Third, a meeting is arranged where the parties work out their respective rankings and where the onus on proving a claim lies. Fourthly, the lesser ranking participant then must by reference to genealogy, oratory, and if need be force, argue their case to be treated as meriting serious treatment as equals or superiors on this matter. Fifthly, the parties now deal directly with each other. Finally if no consensus is reached and reconciliation is not forthcoming, one side seeks judgement from a superior forum.

Kinloch's model of disputes within $f a^{\prime} a$ Samoa began with disagreement, and this was clearly the first step in the 1981 strike. Breaking with tradition the WSPSA decided to avoid the $f a^{\prime} a$ Samoa approach to dispute settlement and opted for the characteristic trade union procedure of direct confrontation. The WSPSA decided to exploit the government's relatively weak position within the parliament. On 1 December 1980 about 4,000 people marched to present a petition to parliament. One report (Wendt, 1981, p.53) suggests that the WSPSA executive expected very few public servants to respond to their call for a march and were pleasantly shocked by the numbers who heeded their call. The petition was initially rejected by the Speaker of the Legislative Assembly on the grounds that Part XV, Article 30 (1) of The General Legislative Assembly Standing Orders required that "A petition may be presented to the Assembly only by a member, who shall affix his name in the beginning thereof." Eventually the petition was presented to parliament by Vaai Kolone, the leader of the opposition Human Rights Protection Party. The petition requested:

a) a 10 percent wage increase from 1 July 1980 for public servants.

b) a small wage increase for all wage workers from 1 July 1980.

c) a 12.5 percent wage increase from 1 January 1981.

The petition was given to the Parliamentary Petition Commission to examine. The Committee consisted only of government members. Not surprisingly the union organised petition for a salary/wage adjustment was rejected by the Committee's report, tabled in parliament on 18 December 1980 (Savali, 24 December 1980). The Committee met on 12 occasions with 34 witnesses. Ulualoaiga Talamaivo Niko, Chairman of the Committee, recommended that parliament approve an eight percent increase in wages and salaries from 1 January 1981 and that $\$ 350,000-\$ 500,000$ be allocated to allow interest free loans to public servants. The Committee specifically advised all public servants to "avoid being involved in politics." This report also estimated that the WSPSA requests would cost about \$3.4 million 
and was thus unaffordable given Western Samoa's economic fragility. The recommendations of the Committee were ratified by the Assembly and thus it appeared that the WSPSA's gamble of bypassing the Cabinet had failed.

The use of a petition as a means of dispute settlement caused great concern for a number of parliamentarians because of a perceived incompatibility between the WSPSA's methods and $f a^{\prime}$ a Samoa. A petition, especially direct from citizens rather than via local matai, was a rare device for Western Samoan politics although a normal Westminster procedure. The parliamentary debate on the petition indicated that some politicians considered that the march and the petition were "un-Samoan" and an "insult" to them as members of parliament and as matai. (Wendt, 1981, p.53).

\section{Key events during the strike}

On the 21 March 1981 the WSPSA met and invited its membership to air views about the Assembly's decision. After this it was decided by the WSPSA executive that a letter should be sent to the Minister of the PSC requesting similar increases as those contained in the already rejected petition. The Minister was given until 31 March 1981 to reply. If the WSPSA executive considered his answer was unsatisfactory a strike would be called on 6 April 1981. The government responded that while they were willing to enter negotiations these should occur through the PSC and its Minister, not at a political level and certainly not with a threat of a strike being held like a 'gun to the head'. On the 6 April the WSPSA Executive met and carried a motion that a strike would be called for an indefinite duration (Savali, 26 June 1981).

The first month of the strike clearly demonstrated a process where the whole relationship between trade unions, strikers and $f a^{\prime} a$ Samoa came into bitter conflict. Government representatives started to relate the strike to a potentially serious threat to $f a^{\prime} a$ Samoa. Throughout the strike the Prime Minister made many references to the fact that he considered "the nub of the problem in the continuing public service strike in Samoa is trying to find a way to slot unionism into the fa' a Samoa." (Kinloch, 1982, p.167).

In terms of the analytical model adopted from Kinloch the second and third stages occurred during this period. Stage two occurred with each party setting out to amass support for their respective claims while the third stage of determining the status in formal Samoan rank between the participants was also a major theme during this period of the strike.

\section{Prime Ministerial statement}

The WSPSA had demonstrated the support for its claims by several means. First, the 4,000 strong protest march, in December 1980, which resulted in the petition to parliament. Second, the leader of the Human Rights Protection Party had delivered the petition to parliament. Third, most public services were severely affected from day one of the strike with essential services only manned on an emergency basis. Fourth, by the end of April three more mass demonstrations in Apia had been held to demonstrate the WSPSA's level of support. Fifth, a strike fund of $\$ 3,000$ had been raised by the WSPSA. Sixth, the WSPSA President, Ieti Tulealo, left for Pago Pago to contact and solicit overseas trade unions, especially public service associations, for support. Finally, the economy was starting to suffer 
with the loss each fortnight of $\$ 5$ million from salaries and a significant shortfall from overseas remittances which were not being delivered by the post office.

The government sought to amass support for its position by appeals warning of the threat to Western Samoa's economic and political stability and further appeals to traditional authority in the villages especially on Savaii. Shortly after the WSPSA took strike action the Prime Minister made a radio broadcast to the nation. General consensus held that the speech helped to crystallise divisions not only within Apia but in the more remote villages which to that time had little involvement with the strike. (Kinloch, 1982, p.166). As one observer noted:

... not content simply to reiterate that the salary adjustments could not be granted immediately (because the government did not have any money), the government accused public servants of inefficiency and theft, charges which might be true for a handful of public servants but could not be extended to all of them (Va'a, 1983, p.90).

During late April and early May 1981 negotiations continued between the WSPSA, the Minister responsible for the public service and the PSC Chairman. It quickly became evident that the original issue of the strike, salary increases, was replaced in importance by three other issues. These issues were the reinstatement of strikers, dispute settlement procedures, and the compatibility of unionism and fa' $a$ Samoa. The question of reinstatement arose because under the provisions of the Public Service Act, a public servant who was absent for more than two weeks from their workplace, without valid reason, automatically forfeited their office. The 1977 Act did not, in the interpretation of the government, recognise strike action as constituting a valid reason for absence from the workplace.

The basis for the government's non-recognition of the validity of the strike for reinstatement purposes rested on two premises. First, that the Assembly which passed the Act specifically deleted provisions relating to strikes. Therefore the current government could not interpret the Act to read those same strike provisions back into the Act. Second, the government felt that it had no mandate to accept strikes as part of the social and political fabric of Western Samoa.

The question of dispute settlement procedures continued to become increasingly important as the strike continued. The WSPSA pushed for recourse to independent arbitration under the Arbitration Act of 1976. The government rejected this argument on the same grounds as its refusal to recognise strikers under the Public Service Act. The government argued that parliament, when passing the 1976 Act, never intended it to apply to strikers. Later, during the closing stages of the strike, in a letter of 12 June 1981 addressed to the Chairman of the PSC, Aliimuamua Esekia, the WSPSA maintained that there was "a real need for PSC to urge the government to promote legislation to introduce conciliation/arbitration or dispute settlement procedures in the public service as exist in the Labour and Employment Act 1972" (Savali, 26 June 1981).

A clear conflict along the lines of formal status determination occurred early in the strike. The WSPSA petitioned Prime Minister, Tupuola Efi, calling for the resignation of Asi Eikene, Minister for the PSC. The demand followed a meeting between the WSPSA and Eikene where the WSPSA were dismissed as they "did not match up in rank to justify their sitting down to discuss ..." (Kinloch, 1982, pp.164-165). Eikene viewed the position between himself, as representing the government, and the WSPSA Executive as that of a contest between an ali' $i$ (chief) and a taule'ale' $a$ (untitled youth). Therefore in his mind there was no merit in the WSPSA's challenging the government.

The theme of unionism and its place, if any, within fa' $a$ Samo $a$ was a constant thread throughout the strike. The President of the WSPSA was interviewed on a New Zealand radio 
program and was reported to have said that fa' a Samoa and unionism were not incompatible and in any event $f a^{\prime} a$ Samoa was open to wide interpretation (Kinloch, 1982, p.167). Tupuola Efi speaking on New Zealand radio towards the end of the strike made the following comments:

a method of solving industrial problems had to be fitted into the very core of our soul, so that it is part of our bloodstream. Although there would be resistance, the test of leadership would be to make it part of the heritage of the people, without upsetting the applecart. This is what the test is about, this is why the strike is taking so long, this is why we are agonising, groping for a norm. It would take time to work to a consensus. If we play it wrong then we are going to sow the seeds of something we are going to regret in the future ... This is what it is about. It is not merely a question of money, of the cost of living, it's more a question of what motivates people, what values they have, how do we go about deciding these things (Kinloch, 1982, p.167).

\section{Intervention by the Prime Minister.}

The next significant event during the strike was the direct intervention of the Prime Minister on 29 April 1981. Until this point Tupuola Efi had refused any direct involvement in the day-to-day dealings with the WSPSA. His decision in part reflected the increasing seriousness of the effects of the strike and the growing impasse between the WSPSA executive and Eikene. According to Kinloch's model the fourth stage of the dispute had been reached. The WSPSA faced with a refusal by the government to accept the union leadership, as having insufficient traditional status, resorted to force in the form of a strike. This forced the Prime Minister to negotiate directly with the WSPSA and thus in fa' $a$ Samoan terms treat the union leadership as being formally recognised.

Initially the Prime Minister's efforts seemed to have broken the impasse. After 40 hours of continuous discussions a softening of positions started to emerge. The WSPSA modified its demand for retrospectivity of salary increases naming February 1981 as the new commencement date. The government still maintained that salary increases could only apply from June 1981 but offered to set up a special independent commission to look into the question of salaries. The Commission was to be chaired by Tofilau Eti with a membership representing various community interests. The findings of the Commission were to be binding on the government. The WSPSA was offered the opportunity to help draw up the Commission's terms of reference and select its membership (Savali, 26 June 1981).

Nevertheless the Prime Minister's intervention made no further ground towards achieving a full settlement of the strike. While the parties seemed to have come closer on the issue of salaries the question of reinstatement became a greater obstacle. The WSPSA refused any involvement with the proposed Commission and insisted that the dispute should be put to arbitration under the 1976 Arbitration Act. The government advised the PSC, who accepted the advice, that all strikers be offered a return to work under the terms of a grant of special leave with a full guarantee of status and entitlements. The WSPSA rejected this offer. It seems that the WSPSA wanted the reinstatement mechanism of the Public Service Act 1977 used so as to legitimate the current strike and the general issue of a "right to strike." (Savali, 26 June 1981). 
Western Samoa Trade Unionism 79

\section{Appeals to higher forums}

The final period of the strike revolved around the participants seeking judgement from various authorities. This corresponds to the final stages of Kinloch's model. As the conflict could not be settled via resort to status considerations each party now sought to settle the matter in a higher forum. Drawing from Kinloch's analogy the parties were now seeking settlement in bodies akin to the village council (fono ) or the Land Titles Court. As with other types of disputes the art is to seek judgement in a forum that is likely to be the most sympathetic. The government sought first to resolve the strike by appealing to the Executive Council. In turn the Council sought to resolve the dispute by using a commission of enquiry whose findings were to be final. The WSPSA, while continuing the strike and other forms of protest action, sought to resolve the dispute in Western Samoa's Supreme Court. In the final settlement of the dispute both of these dispute resolution avenues played key roles.

\section{The Executive Council and Commission of Enquiry}

On 7 May 1981 the highest formal decision-making body in Western Samoa, the Executive Council met to consider the strike (Pacific Islands Monthly, July 1981, p.13). The Executive Council comprised the Head of State, Malietoa Tanumafili, the Cabinet, and the sole member, at that time, of the Council of Deputies. This decision making body qualifies for the title "highest" not only on the grounds of its formal constitutional supremacy but from its standing within fa' a Samoa. Tanunafili was criticised by sections of the WSPSA for his involvement in this meeting (Wendt, 1982, p.53). That criticism appears paradoxical given previous calls from the WSPSA for the Head of State to intervene in the dispute to dissolve parliament and/or sack the government.

The Executive Council made three decisions concerning the strike. First, a Commission of Enquiry would proceed. Secondly there would be no pay for strikers for the period they were on strike and thirdly the offer of a special grant of leave would be withdrawn by $4 \mathrm{pm}$ 11 May 1981. The WSPSA responded to this deadline with a protest march of 10,000 supporters on 11 May. The next day the Prime Minister and the WSPSA met for the last time and direct negotiations were abandoned. On 14 May the Prime Minister declared that the Executive Council's decisions represented the government's final position (Pacific Islands Monthly, July 1981, p.13). On 22 May The Samoan Times reported that 60 percent of public servants were still on strike. The weekend of 23-24 May saw a two day strike by Electrical Power Corporation workers in support of the strike.

The Commission of Enquiry initially met on the 11-12 May 1981 to draw up a list of potential witnesses and to arrange sitting times and locations. As expected Tile Laumea, the Public Service Association representative, did not attend any of the sittings of the Commission. The Commission held two separate sittings in Apia and and met for two days on Savaii. ${ }^{4}$ A total of 55 witnesses appeared before the Commission but no one formally appeared representing the views of the strikers or of the WSPSA as an organisation. Twenty five of the witnesses were from the Savaii and mainly represented the interests of small

\footnotetext{
'The members of the Commission were: Tofilau Eti (Chairman), William Keil (Vice-Chairman), Epa Tuioti (Secretary), Tauti Fuatau, Su'aaiono Rudy, and Aliimalemanu Sasa Tevita. See Savali, 22 July 1981 for a list of wimesses who appeared before the Commission.
} 
planters. They advocated a reduction in the numbers of public servants, an increase in the efficiency of the public service, and for any wage increases to public servants to be matched by concessions to agricultural producers.

The Commission submitted its interim report on 29 May 1981 and the Executive Council fully endorsed the Commission's findings the next day. In formulating its proposals the Commission had been instructed by the Executive Council to have special regard to any impact on the cost of living in Western Samoa, the general state of the Western Samoa economy, and to the ways and means of increasing current revenues to match any proposed salary increase and to determine effects of such measures. While the Commission of Enquiry's report resolved the dispute over wages it failed to address the further issues of reinstatement, dispute settlement procedures and the interaction between $f a^{\prime} a$ Samo $a$ and trade unionism.

The Commission recommended salary increases for the public servants on a sliding scale. At one end of the scale the lowest paid workers received a 32 percent salary increase. This was progressively reduced for higher salaries to a minimum increase of 5 percent for senior public servants. The salary increases were to be effective from 1 June 1981 . The Commission stated that the wage increases were substantial when "considering the state of the economy and in particular the export earning capacity of the country" (Savali, 22 July 1981). The Commission's other findings included that the public service was overstaffed by 20 percent, the role of the PSC as an employment agency would need to be changed due to the cost of the proposed wage increase, and that there would need to be a reassessment by the government with "regard to departmental functions and responsibilities and manpower requirements in the light of the overall economy of the country." (Savali, 22 July 1981).

The news of the government's approval of the Commission's proposals for wage increases was released via radio on 30 May (Savali, 26 June 1981). The WSPSA Executive met on June 1 and decided to continue demonstrations during the Independence Day Celebrations with the focus on the question of reinstatement and some form of payment to offset losses during the strike. The main hope for success for the WSPSA on the issue of reinstatement was the legal action they had instituted in the Supreme Court of Western Samoa.

The events surrounding the 19th annual celebrations of Western Samoa's independence reflected the depth of the social divisions caused by the strike. The government restricted official functions to one day, June 1, instead of the normal three day period of celebrations. The WSPSA used the following two days to demonstrate the strength of their supporter's backing, including the holdings of pro-WSPSA festivities and a march by 10,000 supporters. The Observer of 5 June commented: "If public attendance at the two separate independence celebrations is a criterion indicating in which direction public sympathy and support were bending, then the WSPSA rally was decidedly the one" (Pacific Islands Monthly, July 1981, p.68).

\section{Supreme Court case}

When discussions between the WSPSA and PSC became deadlocked the WSPSA solicitor, Aeau Semi Epati, sought a Supreme Court declaratory judgment on three matters. These matters were finally decided by Chief Justice St John on 9 June 1981. 
Question 1. Could arbitration under the Arbitration Act 1976 be used to resolve the current industrial dispute between the PSA and the PSC?

The Chief Justice ruled that since none of the parties had taken the matter to arbitration it was a hypothetical question on which he could make no decision.

Question 2. What was the proper operation of the 1978 Public Service Regulation 13 Special Leave?

Regulation 13 reads: Special Leave; In special circumstances the PSC may grant any employee special leave of absence with or without pay on terms and conditions it deems fit.

The Chief Justice ruled that once an employee of the public service had been absent for the requisite 14 days, he was automatically dismissed from the service and Regulation 13 could not be applied to a non-employee.

Question 3. What was the proper procedure for valid reinstatement under the Public Service Act 1977 ?

Section 39 of the Public Service Act 1977 states:

Unauthorised Absence (1) Notwithstanding the provisions of SS32,33 and 34 of the Act an employee who absents himself from duty, or who fails to return to duty, and (in either case) continues to be absent without permission for a period of not less than 2 weeks shall be deemed to have forfeited office.

(2) If the employee subsequently satisfies the Commission that there is a valid reason for his absence and for his failure to inform the Commission earlier of the reason the Commission may reinstate the employee; and in such case the employee shall be deemed not to have forfeited office, but to have been on leave without pay from the public service during the period of absence.

The ruling stated that "the commission could not come to the decision that the striking officers had a valid reason for absenting themselves from work."

To help the PSC overcome the problem of appearing to 'legitimate' all strikes, St John noted that this action was an administrative decision and thus no binding precedents would be set if the PSC decided to reinstate strikers this time. On the first day of hearings ( 5 June 1981) the government formally announced the full recommendations of the Commission of Enquiry on wage increases for public servants. The WSPSA withheld any comment or reaction to the government's announcement declaring that any response would have to await the outcome of the Supreme Court case (Savali, 26 June 1981).

\section{A slow end to the strike}

After 8 June, the WSPSA and PSC reopened negotiations on the basis of the Supreme Court declaration. The court judgment was only concerned with the conditions under which the public service would return to work if an agreement was negotiated between the WSPSA, PSC and the government. It was not concerned with the actual terms and merits of the wage case. The WSPSA put forward its proposals on the wage claim and reinstatement to the PSC in writing and the PSC provided a written response. The PSC then announced that permanent

This section is taken from Tuisau, 1982, pp.80-1. 
public servants would be reinstated while casual staff would be re-employed at the discretion of the various departmental heads. There was a last minute hiccup that threatened the settlement but this was quickly resolved (Pacific Islands Monthly, August 1981, p.15). The strike formally ended on 2 July 1981 after nearly 90 days of industrial unrest. In assessing the success of the strikers Meleisea noted that in the long run no salary increase was paid and therefore ultimately the strikers were the losers (Meleisea, 1987, p.233).

\section{Fa'a Samoa and trade unionism}

The 1981 strike represented, on one level, a clash between the demands of a foreign institution based on Western liberal democratic precepts and the demands of fa' a Samoa. Kinloch (1982, p.163) noted that the union leaders borrowed the mechanism of the strike and attempted to give it meaning in the context of Samoa culture. As a dispute solving mechanism in Samoan society the strike was an alien, and therefore difficult beast for Samoans to deal with. The 1981 strike demonstrated the methods used by Samoans to accommodate seemingly incompatible ideas and institutions. Albert Wendt (1981, p.56) noted: "Trade unionism is here to stay. Some of us welcome it and believe our culture can accommodate it like it accommodated Christianity, parliamentary democracy, rugby football, boxing and icecream".

The government came under strong criticism for attempting to break the strike by urging the matai to use their traditional authority to influence strikers to return to work. The strikers felt angry at the matai who they saw as trying to infringe their right to undertake industrial action against the government. Other matai who did not follow the government's advice were seen by fellow matai as refusing to uphold the existing balance of authority in Samoan society. ${ }^{6}$ The use of matai is a classic means of resolving disputes within Samoan society. Throughout the strike both sides attempted to gain legitimacy within the perspective of the ideals and norms of $f a^{\prime} a$ Samoa but at the same time wanted to slot unionism into fa' a Samoa. This was often difficult because the strike revealed the very strong hold that families and villages still held over urban based civil servants. The WSPSA was only able to prolong the strike for as long as it did because the strikers went into the villages and garnered support especially in the form of food (Kinloch, 1982, p.166). Meleisea observed of the strike and its effects that "it is still impossible for Samoans to rise above the pressures of aiga and traditional status values and collective loyalties" (Meleisea and Schoeffel, 1983, p.108). Kinloch (1982, p.171) made these observations about the strike:

They resolved a conflict they had generated by importing an institution from another culture. They did not succeed in establishing the right to strike but they did succeed in establishing precedents for resolving future industrial disputes. Above all the precedents thus established while not wholly Samoan are well grounded in Samoan tradition.

In many ways the analysis I have presented of the 1981 strike is an extension and development of Kinloch's approach. The benefits of applying the concept of mutual adjustment, to accompany an analysis like Kinloch's is a sharper focus on the interactive process between external and internal elements of Western Samoan industrial relations. This study raises a number of further important considerations about trade unionism in Western Samoa. I have left uncovered the period from 1981 to the present day because I feel it warrants its own special study. Such a study would need to include the role of women within

${ }^{6}$ Keesing's Contemporary Archives, September 1983, 32370-32371. 
the union movement and the contributions made by the Western Samoan trade union movement to the labour movement in the region and within international forums. Other issues would include the nature of the relationship between Western Samoan trade unions and political parties or groupings like the Human Rights Protection Party, and the impact that trade unionism had on the changes to Western Samoa's electoral system during 1990 and 1991. From the perspective of the analysis used in this study the most pressing research would be directed at examining the accommodations made in the nature and operations of the WSPSA after a dozen or so years of operation since its re-emergence in 1979.

\section{References}

Ananaba, W. (1979), The Trade Union Moviment in Africa: Promise and Performance, New York, St Martin's Press.

Davidson, J. (1967), Samoa mo Samoa, Melbourne, Oxford University Press.

de Bres, J. (1980), Report of a Visit to Western Samoa in April 1980 as a Guest of the Western Samoan Public Service Association, Presented to the New Zealand Public Service Association.

Epstein, E. (April 1978-79), Control and Co-optation of the Argentine Labor Movement, Economic Development and Cultural Change, 27 (3): 445-465.

Field, M. (1984), Mau: Samoa's Struggle Against New Zealand Oppression, Wellington, A.H. \& A.W. Reed.

Friedland, W. (1972), The Contemporary Role of African Trade Unions, Africa Today, 19 (2): .17-21.

Hess, M. (1986), Unionism and Economic Development: a Papua New Guinea Case Study, Ph.D. thesis, University of New South Wales.

Hoogvelt, A. (1977), The Sociology of Developing Societies, New Jersey, Humanities Press.

Howe, K. (1988), Where the Waves Fall, Honolulu, University of Hawaii Press.

Huntington, S., and Dominguez J. (1975), Political Development, In F. Greenstein, and N. Polsby, (Eds) Macropolitical Theory, Handbook of Political Science Vol. 3, Reading, Massachusetts, Addison-Wesley Publishing Company: 1-114.

Kassalow, E. (1969), Trade Unions and Industrial Relations: an International Comparison, New York, Random House.

Keesing's Contemporary Archives (September 1983), 29: 32370-1.

Kinloch, P. (1982), The Strike in Samoa: an Interpretation, Pacific Viewpoint, 23 (2): 161-172.

Leckie, J. (1990), Preamble. In C. Moore, J. Leckie, and D. Munro (Eds), Labour in the South Pacific, 
James Cook University of Northern Queensland, Townsville: xiii-xvii.

Meleisea, M. (1987), The Making of Modern Samoa: Traditional Authority and Colonial Administration in the History of Western Samoa, Fiji, Institute of Pacific Studies of the University of the South Pacific.

Meleisea, M. and Schoeffel, P. (1983), Western Samoa: Like a Slippery Fish, In R. Crocombe and A. Ali (Eds), Politics in Polynesia, Fiji, Institute of Pacific Studies of the University of the South Pacific.

Pacific Islands Monthly (July-August 1981).

Riggs, F. (1967), The Theory of Political Development, In J.C.Charlesworth (Ed), Contemporary Political Analysis, New York, The Free Press: 317-349.

Rivkin, A. (1969), Nation-building in Africa: Problems and Prospects, J. Morrow (Ed), New Brunswick, Rutgers University Press.

Rustow, D. (1968), Modernization and Comparative Politics, Comparative Politics, 1(1): 37-51.

Sclafani, J. (1977), Trade Unionism in an African State: the Railway and Ports Workers' Union of TUC (Ghana), Ph.D. dissertation, Brown University, USA.

Savali (1979-1981).

Siddique, S.A. (1989), Industrial Relations in a Third World Setting: a Possible Model, The Journal of Industrial Relations, September: 385-401.

South Pacific Commission (1981), South Pacific Economies 1979: Statistical Summary, Noumea, South Pacific Commission: 22-29.

Tuiasau, N. (1982), Post-Mortem on the Samoan Strike, Pacific Perspectives, 10(2): 75-82.

Tyler, C. (1982), Trade Unionism in Brazil, Third World Quarterly, 4(2): 312-320.

Va'a, F. (1983), General Elections in Western Samoa, 1979-82, Political Science, 35(1): 78-102.

Wendt, A. (1981), Western Samoa's First Strike: a Foreign Invention which became Samoan Overnight?, Pacific Perspectives, 10(1): 45-56. 